\title{
THE PROTECTION OF THE FUNDAMENTAL RIGHTS OF THE CHILD IN THE LIGHT OF THE AFRICAN CHARTER ON THE RIGHTS AND WELFARE OF THE CHILD
}

\begin{abstract}
Aвstract. Diallo Boubacar Sidi, The Protection of the Fundamental Rights of the Child in the Light of the African Charter on the Rights and Welfare of the Child [Ochrona podstawowych praw dziecka w świetle Afrykańskiej Karty Praw i Dobrobytu Dziecka]. Studia Edukacyjne nr 49, 2018, Poznań 2018, pp. 175-184. Adam Mickiewicz University Press. ISSN 1233-6688. DOI: 10.14746/se.2018.49.11

The adoption of a binding international treaty on the rights of the child is presented by practitioners and researchers as a "revolution", marking the transition from the legal status of the child as a subject of the right, to a full actor of rights protection. For the fundamental rights of the child not to remain merely theoretical, but to become concrete and meaningful, it is important to provide them with effective judicial protection. This issue is more than ever topical, with the adoption by the United Nations General Assembly of the Optional Protocol to the Convention on the Rights of the Child establishing a procedure for the submission of communications, which entered into force on 14 April 2014. This new Optional Protocol gives children the right to appeal to the Committee on the Rights of the Child when the rights protected by the Convention and its first two protocols are violated. The purpose of this brief study is to analyze the African Charter on the Rights and Welfare of the Child (African Charter), adopted in 1990, which is the first regional legal text for children specifically and as such unique, since no other region in the world has so far developed such a protection mechanism.
\end{abstract}

Key words: human right, child, convention, region, UA, UN

\section{Introduction}

The protection of children's rights and freedoms is closely linked to society's conception of the child. " "With the advent of the enlightenment, the

${ }^{1}$ In this contribution, the child is synonymous with a minor, within the meaning of Article 1 of the International Convention on the Rights of the Child, "every human being under the age of eighteen, unless the majority is reached earlier under the legislation applicable to it". 
democratic revolutions and the proclamation of the equal rights of all human beings, the child was given the status of a human being in their own right. ${ }^{2 \prime \prime}$ Until the second half of the twentieth century, however, the child was still regarded as a mere object of law that needed to be protected. The child rights movement will establish the principle that the child must be able to exercise their rights themselves. International efforts to promote the rights of the child have dramatically changed its status from a relatively weak subject to a full rights holder whereby the child is no longer a subject, but now an actor. ${ }^{3}$ The texts that proclaim the fundamental, general and specific rights of the child are numerous. In order for these rights not to remain merely theoretical and illusory, but to become concrete and meaningful, it is important to provide them with effective judicial protection and, in the light of the child's vulnerability and specificities, make them child friendly. However, to date, national jurisdictional mechanisms to protect the rights of the child can be seen to be largely inadequate. It is therefore at the regional and at the universal level that the most relevant systems of child rights protection are developed.

As we can see, Africa has followed an initiative due to the United Nations and this is also the case for the Charter of the Rights and Wellbeing of the African Child (CRWAC). On the one hand, this follows very closely, at least chronologically, not to mention that it refers to it expressly, as per the Convention on the Rights of the Child (CRC) opened for signature, ratification and accession by General Assembly resolution 44/25 of the United Nations of 20 November 1989. On the other hand, in doing so, the OAU intended to present it as Africa's contribution to the cause of children at the World Summit for Children which took place in New York on 29 and 30 September 1990, the principle of which had previously been supported by many African states.

\section{The fundamental rights of the child in the legal world}

Human rights and fundamental freedoms, protected in universal or regional texts, belong to both children and adults. Some provisions specifically target them. In addition to the general protection they enjoy, children are granted enhanced or specific protection of their fundamental rights. ${ }^{4}$ This

2 See: J.-L. Renchon, Les droits de l'enfant dans le conflit parental, [in:] Enfants, sujet de droits: rêve ou réalité?, éd. du Jeune barreau de Liège, Liège 1995, p. 154.

${ }^{3}$ See: E. Brems, Inclusive universality and the child-caretaker dynamic, dans K. Hanson et O. Nieuwenhuys (dir.), Reconceptualizing children's rights in international development. Living rights, social justice, translations Cambridge, 2013, Angleterre: Cambridge University.

4 See: Pacte international relatif aux droits civils et politiques, 16 décembre 1966, 999 R.T.N.U. 171 (entré en vigueur le 23 mars 1976); Pacte international relatif aux droits économiques, sociaux et culturels, 16 décembre 1966, 993 R.T.N.U. 3 (entré en vigueur le 3 janvier 1976); See: 
results from their fragility and their general inability to exercise their rights themselves. ${ }^{5}$ The specific protection of the rights of the child lies essentially in the International Convention on the Rights of the Child. This Convention is the fruit of a reflection that began, in law, with the "Geneva Declaration on the Rights of the Child", adopted unanimously in 1924 by the League of Nations. It was a simple moral commitment and not a legally binding text. Children were seen as vulnerable beings who needed to be protected, but not as subjects of law. The second declaration on the fundamental rights of the child was adopted unanimously on 20 November 1959 by the United Nations General Assembly. This "Universal Declaration of the Rights of the Child can be seen as the embryo of a change of attitude towards the rights of the child. While the 1924 Declaration was limited to an enumeration of broad principles, the 1959 Declaration is more persuasive in terms of content. It includes a preamble and ten main principles. The aim is to translate and adapt the guidelines of the Universal Declaration of Human Rights to the situation of children. ${ }^{\prime \prime}$

The non-binding Declaration of 1959, however, remains focused on the protectionist aspect of the rights of the child and does not grant them autonomy or recognize their progressive capacity. Thirty years later, the legally binding Convention on the Rights of the Child is born. It is almost universal, having been ratified to date almost by all States. Only the United States, which signed it on 16 February 1995, is in default of accession, because "the death

Convention européenne de sauvegarde des droits de l'homme et des libertés fondamentales, 4 novembre 1950, S.T.E. no 5 (entrée en vigueur le 3 septembre 1953); Charte sociale européenne révisée, 3 mai 1996, S.T.E. no 163 (entrée en vigueur le 1er juillet 1999); Charte des droits fondamentaux de l'Union européenne, 7 décembre 2000, J.O.C.E. no 2000/C 364/01 du 18 décembre 2000 (entrée en vigueur le 1er décembre 2009 par le truchement de l'article 6 du Traité de Lisbonne modifiant le Traité sur l'Union européenne et le Traité instituant la Communauté européenne, 13 décembre 2007, J.O.U.E. no 2007/C-306/01 du 17 décembre 2007); zob: l'article 2 du Pacte international relatif aux droits civils et politiques et Comité des droits de l'homme, Observation générale no 17 « Article 24 » (trente-cinquième session, 1989), U.N. Doc. HRI \GEN\1\ Rev.1 (1994); l'article 1er de la Convention européenne des droits de l'homme; Par exemple, article 24 du Pacte international relatif aux droits civils et politiques; article 10, § 3, du Pacte international relatif aux droits économiques, sociaux et culturels; article 24 de la Charte de l'Union européenne; article 5 de la Convention européenne des droits de l'homme; articles 7 et 17 de la Charte sociale européenne.

${ }^{5}$ Ph. Bonfils, A. Gouttenoire, Droit des mineurs, Paris 2014, s. 5 et 24; F. Delpérée, La Constitution belge et la Convention relative aux droits de l'enfant, [in:] La Convention sur les droits de l'enfant et la Belgique, M.-Th. Meulders-Klein (dir.), Bruxelles 1992, p. 92; M. Freeman, A Commentary on the United Nations Convention on the righs of the child - Article 3 - The best interests of the child, Leiden 2007, p. 9; Rh. Smith, The Third Optional Protocol to the UN Convention on the Rights of the Child? - Challenges Arising Transforming the Rhetoric into Reality, International Journal of Children's Rights, 2013, p. 306.

${ }^{6}$ T. Hammarberg, in Janusz Korczak - Le droit de l'enfant au respect - L'héritage de Janusz Korczak - Conférences sur les enjeux actuels pour l'enfance, éd. Conseil de l'Europe, Strasbourg 2009 , p. 7. 
penalty remains in theory still applicable to minors in some States, even if the Supreme Court has asserted that this was no longer the case".

The Convention includes both general fundamental rights, civil and political as well as economic, social and cultural, and the fundamental rights specific to children. While it remains essentially protectionist, it contains a series of rights that also support the autonomy of children: "the Convention is thus inspired by a more complete and more contemporary vision of the child."' At the regional level, there are also instruments dedicated specifically to the rights of the child. First of all, the Organization of African Unity (now the African Union in 2002) adopted, on July 11, 1990, the African Charter on the Rights and Welfare of the Child, will be the subject of our analysis through this contribution. ${ }^{8}$ At the European level, until today, there is as yet no general convention on the fundamental rights of the child. The European Convention on the Exercise of the Rights of the Child aims to facilitate "the exercise of the material rights of children by strengthening and creating procedural rights that can be implemented by the children themselves or by the intermediary of other persons or organ "is an interesting instrument. ${ }^{\text {" }}$ However, until now, it has had only limited success and no judicial review has sanctioned the matter of violation, which limits its impact.

\section{The drafting of the African Charter of Rights and Welfare}

The concern to legislate on children's rights in Africa goes back to 1979, the International Year of the Child, when the OAU adopted the Declaration on the Rights and Welfare of the African Child at its 16th ordinary session in Monrovia, Liberia. ${ }^{10}$ This instrument was however not binding. Then, the

${ }^{7}$ F. Viljoen, Supra-national human rights instruments for the protection of children in Africa: The Convention on the Rights of the Child and the African Charter on the Rights and Welfare of the Child, The Comparative and International Law Journal of Southern Africa, 1998, 31, p. 31.

${ }^{8}$ See: Charte africaine sur les droits et le bien-être de l'enfant, adoptée lors de la 26e Conférence des chefs d'État et de gouvernement de l'Organisation de l'Union africaine à Addis-Abeba, Éthiopie, Doc. OUA CAB/LEG/153/Rev.2, juillet 1990 (entrée en vigueur le 29 novembre 1999).

${ }_{9}^{9}$ See: Convention européenne sur l'exercice des droits de l'enfant, 25 janvier 1996, S.T.E. no 160 (entrée en vigueur le 1er juillet 2000).

${ }^{10}$ See: T. Kaime, The foundations of rights in the African Charter on the Rights and Welfare of the Child: A historical and philosophical account, African Journal of Legal Studies, 2009, 4, p. 120-136; D. Mzikenge Chirwa, The merits and demerits of the African Charter on the Rights of the Child; A. Lloyd, Evolution of the African Charter on the Rights and Welfare of the Child and the African Committee of Experts: Raising the gauntlet, The International Journal of Children's Rights, 2002, 10; D. Olowu, Protecting children's rights in Africa: A critique of the African Charter on the Rights and Welfare of the Child; M. Gose, The African Charter on the Rights and Welfare of the Child. 
African Charter on Human and Peoples' Rights, adopted in 1981, also mentioned children in Article 18 (3). The OAU in addition developed various mechanisms for the protection of the rights of the child, particularly in the following areas: child labor, trafficking and situations of armed conflict. For example, with regard to work, the OAU secretariat collaborated with the International Labor Organization's Program on the Elimination of Child Labor (ILO-IPEC), or with the Committee on Social Affairs and Social Welfare to deal with this issue. ${ }^{11}$

As early as 1979, discussions began on the development of a universal United Nations Convention on the Rights of the Child (UNCRC). However, the African continent was under-represented in the working group and only the Algerian, Moroccan and Senegalese delegates were part of it - moreover, on an irregular basis. This modest number of three people contrasted with the large participation rate of the Western European countries. ${ }^{12}$ This low representation also concerned the non-governmental level. It seems that the main reason for this degree of absence was not only the lack of financial resources, the working group meeting most of the time in Geneva, but also the lack of interest in participating in the working group itself. ${ }^{13}$

The Senegalese delegate, who represented all sub-Saharan Africa during this preparatory work, intervened in the discussions to include African culture only at the second reading. At that time, his opinion was not really taken into account, the chairman of the working group declaring that substantial changes to the text were no longer possible. This lack of consideration for African particularities certainly resulted in frustration, with the delegate feeling left out of international negotiations within the UN. ${ }^{14}$ It was not until 1987 that some African leaders, meeting in Nairobi from 6 to 10 July for a conference on children in armed conflict in Africa, heard official talk about the elaboration of the CRC that was under way. The states represented at this conference were: Ethiopia, Mozambique, Nigeria, Somalia, Sudan, Uganda and Zimbabwe. In addition, representatives of UN agencies (High Commissioner for Refugees, UNICEF, World Health Organization), OAU and international non-governmental organizations (ICRC, OXFAM, BICE, Save the Children) were also invited. ${ }^{15}$

${ }^{11}$ A. Lloyd, Evolution of the African Charter, p. 179-198.

${ }^{12}$ T. Kaime, The Convention on the Rights of the Child. A cultural legitimacy critique, Groningen 2011, p. 35.

${ }^{13}$ D. Johnson, Cultural and regional pluralism in the drafting of the UN Convention on the Rights of the Child, [in:] The ideologies or children's rights, M. Freeman et P. Veerman (dir.), Dordrecht 1992, p. 95-114.

${ }_{14}$ See: F. Viljoen, Supra-national human rights instruments, p. 199-205.

15 See: A.S. Wako, Towards an African Charter on the Rights of the Child, dans ANPPCAN (dir.), The Rights of the Child. Selected Proceedings of a Workshop on the Draft Convention 
It was on this occasion that the participants realized that few African countries had been included in the process of developing the CRC. As a result, they mandated the African non-governmental organization ANPPCAN, which was the organizer of the conference, to set up a regional meeting to examine the text of the CRC from an African perspective (ANPPCAN. ANPPCAN did so and convened a wide range of African representatives at the United Nations Headquarters in Nairobi from 9 to 11 May 1988, with the support of UNICEF). ${ }^{16}$ The participants were mainly African lawyers, judges and academics, and represented 17 African countries (ANPPCAN, personal communication, 17 September 2013). The main objectives of this "workshop on the rights of the child" were to take a position on the CRC and to decide whether it seemed necessary to supplement it with a regional instrument.

Although participants at this workshop recognized the relevance of the CRC articles in the African context, including the right to life and care, and the need for this instrument to be defined in vague terms to aim for accession universal, the conclusion that emerged was that a charter specifically addressed to African children was necessary. Indeed, the need to consider African cultural particularities was expressed. The aspects considered essential and not included in the CRC when we spoke of the protection of the African child at the time were: the children living under the apartheid regime, the special living conditions in Africa, female genital mutilation, displaced and refugee children, and the responsibilities of the child to others. ${ }^{17}$

In addition, the definition of the child contained in the CRC was considered imprecise, giving signatories the option of setting an age of under 18 years. Finally, the minimum age of 15 to participate in armed conflict was considered too low. It was pointed out that the African instrument would simply complement the CRC to assist its implementation at the regional level and would not be in any way in conflict with it. At the end of the meeting, it was recommended that a working group made up of African specialists from various disciplines be set up to prepare the text of the future charter and then be considered by the heads of African governments. These experts were appointed by delegates present at the meeting and came from universities and international NGOs (ANPPCAN, personal communication, 17 September 2013). This "Expert Committee", composed of professionals from both medical and social sciences, met several times during 1989 and was tasked with defining the various aspects to be covered by the Charter. The result was a first text that circulated at the continent level in various networks of experts, in order to collect as many comments as possible. Finally, a global document

on the Rights of the Child: An African Perspective, Nairobi, Kenya, 9-11 May, 1988 (p. 41-47); Nairobi, Kenya: 1989, English Press.

${ }^{16}$ See: Ibidem, p. 47.

17 See: D. Johnson, Cultural and regional pluralism. 
was produced and the experts met for four days the same year to deliberate and present a draft of the charter. ${ }^{18}$

The final version of the document was placed in the hands of a legal team with extensive experience in document development. It was this final version of the charter that was sent to the OAU Secretary General, who passed it on to all African heads of state. Some amendments to the text were made and the Secretary General of the OAU presented it to the Assembly of Heads of State and Government of the OAU at its 26th ordinary session in Addis Ababa on 11 July 1990, where it was adopted. The African Charter on the Rights and Welfare of the Child (ACRWC) was then officially opened for signature and ratification, representing the first regional legal instrument on the rights of the child. However, Article 47 (3) of the said document stipulates that 15 ratifications are necessary for its entry into force. The entry into force took place on 29 November 1999, almost ten years after the adoption, following the fifteenth ratification. Currently, 47 states are party to the African Charter, out of the 55 Member States of the African Union. It seems that this instrument was born of an "African effort". The African Charter is prima facie a pioneering instrument with more than a more comprehensive monitoring mechanism than the CRC. This is indeed the African Committee of Experts on the Rights and Welfare of the Child (African Committee).

\section{Some relevant aspects of the African Charter on the Rights and Welfare of the Child}

The first characteristic that emerges from the reading of the African Charter on the Rights and Welfare of the Child is the vagueness of its scope ratione personae to the extent that by "child" it means "every human being under the age of 18 "(Article 2); a triple problem arises in this respect whose stake is far from being negligible, since its solution depends on the applicability of a whole protective regime. ${ }^{19}$ The first criterion for recognition of the "child" category is therefore the maximum age of 18 and in so doing, the African Charter partially adopts the definition of the United Nations Convention on the Rights of the Child. However, during the elaboration of the UN Convention, we have seen African states challenge this majority on the ground that their respective domestic laws admit it only later.

It must therefore be noted that the African states will have to resolve this first difficulty, especially since the provision in question does not seem to al-

18 A. Lloyd, Evolution of the African Charter.

19 See: H. Gherari, La Charte africaine des droits et du bienêtre de l'enfant, Études internationales, 1991, 22(4), p. 735-751. 
low, at least explicitly, derogations. The only solution will be that of resorting to the use of reserves with the thorny issue of accounting in respect to the purpose of the Charter. This will be governed by the Vienna Convention on the Law of Treaties and it should be noted that the Charter is silent on this point.

In the opposite case, where this majority occurs before the age of 18, the solution would appear to be easier because the Charter reaffirms the adherence of African states to the United Nations Convention on the Rights of the Child, which provides for the possibility of more majorities enjoying early warning (Article 2).

When is one considered to have a child? From birth or conception? To this second dilemma the Charter provides no clear answer. While most of the rights conferred assume that the child is already born, there remains one, fundamental issue, which raises many questions: the right to life and survival (Article 5). Thus, the never-ending debate on abortion following the United Nations Convention cited above has not been settled and one can easily guess the opposition of certain States to such a subject.

The third difficulty arises as to whether it is necessary to distinguish between legitimate children and natural children. A negative answer is necessary because the definition of Article 2 above and especially Article 3 of the Charter establish the principle of non-discrimination, especially since among the prohibited criteria of distinction there is one from "birth". Such a conclusion is in harmony with one of the key principles of human rights: non-discrimination, as found in the African Charter on Human and Peoples' Rights (Article 2), ${ }^{20}$ the United Nations Convention on the Rights of the Child (Article 2, \$1), the International Covenant on Civil and Political Rights (Article 24, \$1) and the International Covenant on Economic, Social and Cultural Rights (Article 10, §3). Nevertheless, natural children have not been the subject of any specific provision, even though they face particular obstacles. Moreover, some African states, because of their Muslim religion, are likely to be reluctant to accept such equality, since they recognize filiation only through marriage.

\section{Conclusion}

The normative work of the OAU is, of course, to be welcomed in that it reinforces the protection of the rights of the child. Its contribution, however, remains limited in that it largely reflects the normative content of the United

${ }^{20}$ See: E.G. Bello, The African Charter on Human and People's Rights. A légal analysis, Recueil des Cours de l'Académie de Droit International, 1985-V, 194, p. 9-268; F. Ouguergiuz, La Commission africaine des droits de l'homme et des peuples: présentation et bilan d'activités (1988-1989), Annuaire Français de Droit International, 1989. 
Nations Convention on the Rights of the Child. Could it be otherwise though, as soon as children have rights inherent in their human dignity on the one hand and at the same time on the other hand, their specific needs stem from evils common to many parts of the world - especially the Third World? This community of inspiration has the consequence that the Charter, like the aforementioned Convention, will exacerbate the reluctance of certain States to ratify it, its entry into force. This must be pointed out, having been fixed after the submission of 15 instruments of ratification, with a little less than a third of OAU members. The African footprint is nevertheless present and derives from a particular concern and cultural approach to the continent.

These considerations lead us to question the necessity of such a convention. Would it not have been better to encourage African states to be bound by the United Nations Convention, especially since the proliferation of instruments dealing with human rights is not a guarantee of their scrupulous observation. The answer to this question must imperatively take into account the progress of the Charter in the field of the modes of control because in addition to the reports, it has put in place communications rich in perspectives of an examination of attack with regard to individual rights. Because the path has only been partially opened by the Charter, it is necessary to wait for the additional details necessary to decide on the true scope of this innovation.

This article therefore aims to understand the context in which the African Charter was born. Thanks to a collection of information from primary and secondary literature it has been possible to reconstruct a framework for the elaboration of this regional instrument. Subsequently, the paradoxes emerging from the information gathered were identified and it was attempted to analyze them by first locating the creation of the African Charter in the debate that opposes the universalism of human rights to cultural relativism. To conclude on the broader context of the system of protection of the rights of the child in Africa, it is true that it still contains many flaws. However, it has the merit of existing and having represented the first regional mechanism of the rights of the child, leading to considerable and encouraging progress. The limits of the African Charter could probably be overcome with the good will of the Member States as to its translation into national law, as well as through better funding and enlargement of the possibilities of the African Committee.

\section{BIBLIOGRAPHY}

Bello E.G., The African Charter on Human and People's Rights. A légal analysis, Recueil des Cours de l'Académie de Droit International, 1985-V, 194.

Bennouna M., La Convention des Nations Unies relative aux droits de l'enfant, Annuaire Français de Droit International, 1989. 
Bonfils Ph., Gouttenoire A., Droit des mineurs, Dalloz, Paris 2014.

Boukongou J.-D., Le système africain de protection des droits de l'enfant. Exigences universelles et prétentions africaines. Cahiers de la recherche sur les droits fondamentaux, 2006, 5.

Boyden J., Childhood and the policy makers: a comparative perspective on the globalization of childhood, dans A. James, A. Prout (dir.), Constructing and reconstructing childhood: contemporary issues in the sociological study of childhood, Angleterre: The Falmer Press, Londres 1990.

Brems E., Inclusive universality and the child-caretaker dynamic, dans K. Hanson, O. Nieuwenhuys (dir.), Reconceptualizing children's rights in international development. Living rights, social justice, translations, Angleterre: Cambridge University, Cambridge 2013.

Clergerie J.L., L'adoption d'une convention internationale sur les droits de l'enfant, Revue du Droit Public, 1990.

Freeman M., A Commentary on the United Nations Convention on the righs of the child - Article 3 - The best interests of the child, Nijhoff, Leiden 2007.

Gherari H., La Charte africaine des droits et du bienêtre de l'enfant, Études internationales, 1991, 22(4).

Hammarberg T., in Janusz Korczak - Le droit de l'enfant au respect - L'héritage de Janusz Korczak - Conférences sur les enjeux actuels pour l'enfance, éd. Conseil de l'Europe, Strasbourg 2009.

Johnson D., Cultural and regional pluralism in the drafting of the UN Convention on the Rights of the Child, [in:] The ideologies or children's rights, M. Freeman, P. Veerman (dir.), PaysBas: Martinus Nijhoff, Dordrecht 1992.

Kaime T., The foundations of rights in the African Charter on the Rights and Welfare of the Child: A historical and philosophical account, African Journal of Legal Studies, 2009.

Kaime T., The Convention on the Rights of the Child. A cultural legitimacy critique, Pays-Bas: Europa Law Publishing, Groningen 2011.

Lloyd A., Evolution of the African Charter on the Rights and Welfare of the Child and the African Committee of Experts: Raising the gauntlet, The International Journal of Children's Rights, 2002.

Moneger F., La Convention des Nations Unies sur les droits de l'enfant, Revue de Droit Sanitaire et Social, 1990.

Ouguergiuz F., La Commission africaine des droits de l'homme et des peuples: présentation et bilan d'activités (1988-1989), Annuaire Français de Droit International, 1989.

Renchon J.-L., Les droits de l'enfant dans le conflit parental, in Enfants, sujet de droits: rêve ou réalité?, éd. du Jeune barreau de Liège, Liège 1995.

Smith Rh., The Third Optional Protocol to the UN Convention on the Rights of the Child? - Challenges Arising Transforming the Rhetoric into Reality, International Journal of Children's Rights, 2013.

Twum-Danso A., The Convention on the Rights of the Child: A product and facilitator of a global childhood, dans A. Twum-Danso, R. Ame (dir.), Childhoods at the intersection of the local and the global, Angleterre: Palgrave Macmillan, Hampshire 2012.

Viljoen F., Supra-national human rights instruments for the protection of children in Africa: The Convention on the Rights of the Child and the African Charter on the Rights and Welfare of the Child, The Comparative and International Law Journal of Southern Africa, 1998.

Wako A.S., Towards an African Charter on the Rights of the Child, dans ANPPCAN (dir.), The Rights of the Child. Selected Proceedings of a Workshop on the Draft Convention on the Rights of the Child: An African Perspective, Nairobi, Kenya, 9-11 May, 1988; Nairobi, Kenya 1989, English Press. 